\title{
Estimating Plant Macronutrients Using VNIR Spectroradiometry
}

\author{
Balamurugan Mani*, Jayalakshmi Shanmugam \\ Institute of Remote Sensing, Anna University Chennai, India
}

Received: 17 January 2018

Accepted: 27 March 2018

\begin{abstract}
Leaf nutrient levels are traditionally quantified by laboratory chemical analysis, which is time consuming and requires huge investment. The objective of this research is to estimate the nutrient content of groundnut leaves using an assembled visible near-infrared spectroradiometer $(650-900 \mathrm{~nm})$. This method is faster and requires less time and investment compared to conventional chemical analysis. Different fertilizer was applied for different conditions along with one control of groundnut plants. The nutrient deficiency in the groundnut plants was created artificially. The leaf samples were collected in the growth of different days. The samples were analyzed for major nutrient concentrations, which are acquired by field conditions. This research provides the guidelines on the nutrient estimation of the groundnut leaves.

The peak reflectance esteem was seen in the infrared range $(650-900 \mathrm{~nm})$ and the reflectance value was observed for nitrogen $(716 \mathrm{~nm})$, phosphorus $(737 \mathrm{~nm})$, and potassium $(720 \mathrm{~nm})$. This study may provide guidelines for estimating macronutrients and yield estimation of groundnut plants.
\end{abstract}

Keywords: spectroradiometer, groundnut plant, VNIR, leaf nutrient, fertilization

\section{Introduction}

India ranks second in groundnut production of worldwide farmer output [1-2]. The production of agriculture is steadily declining because of drought, lack of rain, irrigation, and fertilization problems. The growth of agriculture is directly affected by polluted air. The morphological properties of crops change due to air pollution, which affects crop tissues and cells [3]. So the pollutants from the air should be reduced in order to improve crop growth [4]. For crop cultivation, the properties of the land have to be determined. The development of agricultural activities

*e-mail: bala.syda@gmail.com was based on field balance, sustainability, and landscape design. A survey of the cropland analysis is used to pre-determine land strengths and weaknesses [5-7]. The agronomic characteristics depend on the soil's water-holding capacity. Soil that holds liberal amounts of water is less subject to draining losses of nutrients and soil-connected pesticides [8]. Water stress plays an important role in the germination of seeds [9-10]. In southern India groundnut production is seriously affected due to the serious problem of nutrient deficiency. The environmental cycle gets affected due to over/under fertilization. Farmers use approximate methods of fertilization treatment [11-12]. By recommending the nutrient at the correct level, yield estimation, the rate consumption, and fertilizer consumption can be saved. Numerous studies involving 
rapid estimation of crop nutrient requirements have been carried out with non-invasive technologies [13]. Various spectroscopic techniques for rapid and non-destructive estimation of plant nutrients have been investigated [14-15]. Visible and near infrared (VIS-NIR) spectrum analysis is one of the most important and commonly used methods [16-17].

For predicting fertilizer consumption, different types of assembled spectroradiometers are used but it can be costly. The research mainly focuses on developing low cost and handiness for easy field use. The newly assembled spectroradiometer was analyzed with the existing system and efficiency was found. The existing system mainly focused on the VNIR spectroradiometer for estimating nutrient substance in groundnut leaves. The produced transmittance and absorbance sorted meters were also used for the reliability of remotely detected nondestructive plant nutrient estimation of the earlier studies. Different varieties of groundnut series (approximately) is cultivated in India. Based on the local soil type, the Tindivanam 07 (TMV07) variety of groundnut series was used in this study.

\section{Materials and Methods}

\section{Soil Sampling and Chemical Analysis}

The soil sample was collected from the rangeland of Kandampakkam village, Villupuram District, Tamilnadu, India. The surface litter of the sampling spot was removed and the soil collection was done by the following procedure: Using an auger, a plough depth of $15 \mathrm{~cm}$ and a $\mathrm{V}$-shaped sample cut was collected from the sampling spot using spade [18]. 10 to 15 samples were collected from each sampling unit and placed in a bucket. The chemical analysis was carried out for the collected soil to evaluate the nutrients in the soil [19]. As per the content of nutrients in the soil acquired by chemical analysis, it is simpler to determine the amount of fertilizer required for the plant.

\section{Soil Preparation}

The collected soil was filled in a jute sack and placed in flowing water until the nutrient concentration of the soil was reduced to $20 \%$ from its original nutrient concentration. The washed soil was filled in a $25 \mathrm{~kg}$ pack for seeding.

\section{Seed Recommendation and Procedure for Cultivation}

Fourteen varieties of groundnut series are cultivated in Tamilnadu. Among them, TMV07 (Tindivanam 07) groundnut series is highly recommended for the selected soil. Each seed was placed at a depth of 5 to $6 \mathrm{~cm}$ with a breadth of $10 \mathrm{~cm}$. The germination of groundnut seed is found to be good if the soil temperature is maintained
Table 1. Combination of fertilizer applied.

\begin{tabular}{|c|c|c|c|}
\hline Fertilizer treatment & $\mathrm{N}(\%)$ & $\mathrm{P}(\%)$ & $\mathrm{K}(\%)$ \\
\hline \multirow{2}{*}{ N treatment } & 50 & 100 & 100 \\
\cline { 2 - 4 } & 75 & 100 & 100 \\
\hline \multirow{2}{*}{ P treatment } & 100 & 50 & 100 \\
\cline { 2 - 4 } & 100 & 75 & 100 \\
\hline \multirow{2}{*}{ K treatment } & 100 & 100 & 50 \\
\cline { 2 - 4 } & 100 & 100 & 75 \\
\hline NPK & 100 & 100 & 100 \\
\hline
\end{tabular}

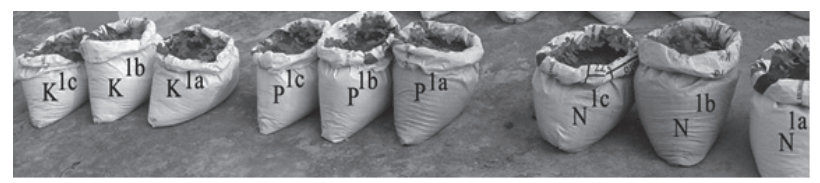

Fig. 1. Combination of fertilizer applied in triplet method.

between $25^{\circ} \mathrm{C}$ and $30^{\circ} \mathrm{C}$ [20]. If the temperature is low there is a delay in germination, leading to seedling disease. So the average atmospheric temperature $\left(28^{\circ} \mathrm{C} \pm 2^{\circ} \mathrm{C}\right)$ is maintained for $100-105$ days for better growth.

\section{Fertilizer Treatment}

The growth of the plant mainly depends on the nutrient content available in the soil. The insufficient nutrient content of the soil drastically affects plant growth and yield [21]. Hence the fertilizer should be mixed with the soil for healthy growth and yield. The $\mathrm{N}$ fertilizer treatment was carried out in two different conditions, consisting of $50 \%$ and $75 \%$ with sufficient nutrient content for $\mathrm{P}$ and $\mathrm{K}$. The same procedure was repeated for $\mathrm{P}$ and $\mathrm{K}$ fertilizer treatment. One control (100\% NPK) condition was also planted for comparison (Table 1). The fertilizer was applied by triplet method, which is shown in Fig. 1.

\section{Spectral Measurement}

The spectral data was collected using the assembled handheld spectroradiometer (Fig. 2), which consists of a transmitter and a receiver. The red and infrared light source was chosen as the transmitter runs between 650 to $900 \mathrm{~nm}$ [22-25]. The TSL235R silicon photo diode (320-1050 $\mathrm{nm})$ light to frequency converter was used as the receiver. An Atmega 328 microcontroller commonly uses an autonomous system which is a simple, user friendly, and low-powered device. The microcontroller consists of an built-in analog-todigital converter and the output is viewed on an LCD display. The Spectroradiometer is connected to a laptop by means of a probe placed above the leaf surface. The most extreme separation between the leaf and 

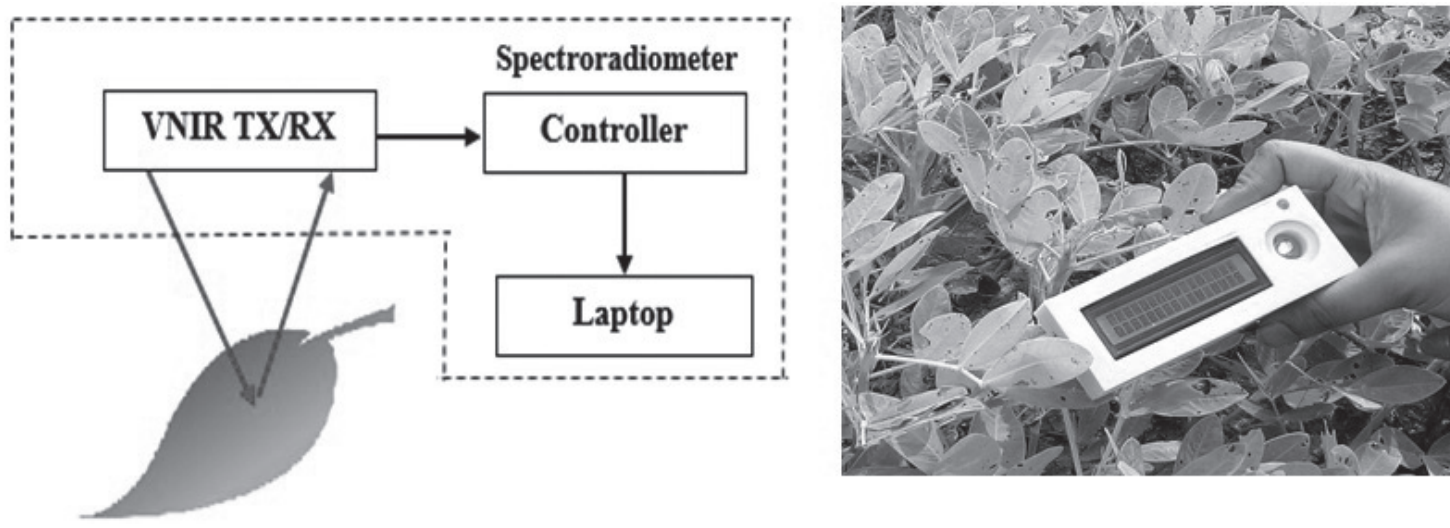

Fig. 2. Spectroradiometer.

spectroradiometer is less than $1 \mathrm{~cm}$ in order to obtain accurate results. If the distance between the leaf and the spectroradiometer varies more than $1 \mathrm{~cm}$, it results in poor accuracy. The lights discharged from the LED were centered and focused on the leaf surface and the reflected light was observed by the receiver. The light from the LED focused on the leaf surface covers an area of $1 \times 2 \mathrm{~mm}$.

\section{Spectra Collection}

The growth of the plant was monitored continuously. In the experiment the deficiency symptoms of plant growth were seen after 30 days. The deficiency symptoms linearly increase to the following days. The symptoms can be found by means of colour variation in leaves [26-30]. The spectral measurement was carried out on four different days: $30,40,50$, and 60. During the measurement, five different leaves were selected from each plant. The leaf colour variation was performed by the following method such as 1-5 scale, where: 1) $1-10 \%$ colour variation; 2) $11-20 \%$ colour variation; 3) $21-50 \%$ colour variation; 4) $51-75 \%$ colour variation; and 5: $>75 \%$ colour variation was selected. The colour variation was not evenly spread over the

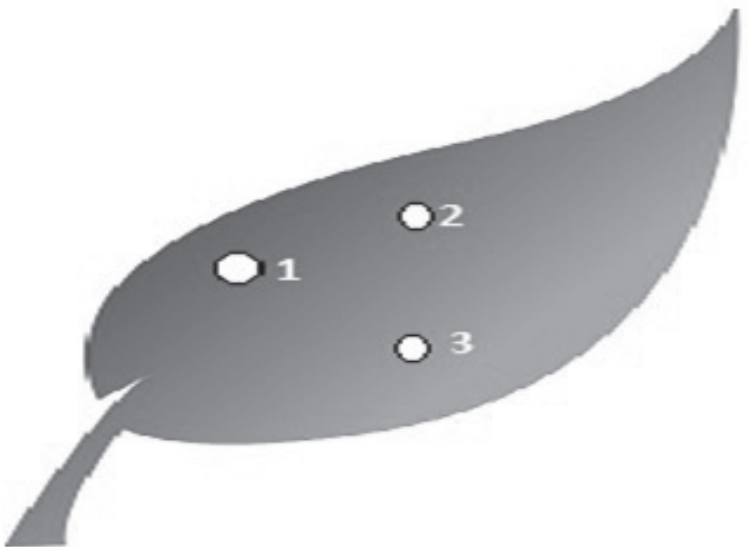

Fig. 3. Location for reflectance measurement of leaf surface. leaf surface and hence the three different measurements were taken in different locations of a leaf, which is shown in Fig. 3. In total 15 readings were taken for each plant. Leaf reflectance deficiency was estimated based on the average of the 15 readings.

\section{Results and Discussion}

From the laboratory analysis, the collected soil sample is found to be sandy loam, which is well suited for groundnut cultivation. From the analysis, the available soil nutrient and deficiency of nutrients in soil was estimated. Table 2 shows that the nutrient deficiency of phosphorus (P) and potassium (K) shows a higher rate [31] when compared with nitrogen $(\mathrm{N})$.

The nutrient content in the soil determines plant growth. The correct proportion of fertilizer is required for healthy plant growth. After cultivation the deficiency of the nutrient in groundnut leaves was evaluated by the spectral reflectance of the assembled spectroradiometer. Spectral reflectance $(650-900 \mathrm{~nm})$ was measured for all treatments on various days. The leaves with nitrogen deficiency show yellow and pale appearance [32-35]. Fig. 4(a, b) shows the percentage reflectance of $25 \%$ and $50 \%$ plant deficiency in nitrogen relative to the wavelength. The slope of the red shift shows the peak reflectance in the wavelength of $716 \mathrm{~nm}$ [36]. The spectral reflectance measurement was observed in various days such as 30, 40, 50, and 60 . It was found that the percentage of spectral reflectance varies accordingly.

Table 2. Available nutrient content and deficiency of nutrients in soil.

\begin{tabular}{|c|c|c|c|}
\hline Macro Nutrient (Kg/acre) & N & P & K \\
\hline Available soil Nutrient & 77 & 5 & 18 \\
\hline Required Nutrient for Groundnut & 99 & 143 & 75 \\
\hline Deficiency of Nutrient in soil & 22 & 138 & 57 \\
\hline
\end{tabular}



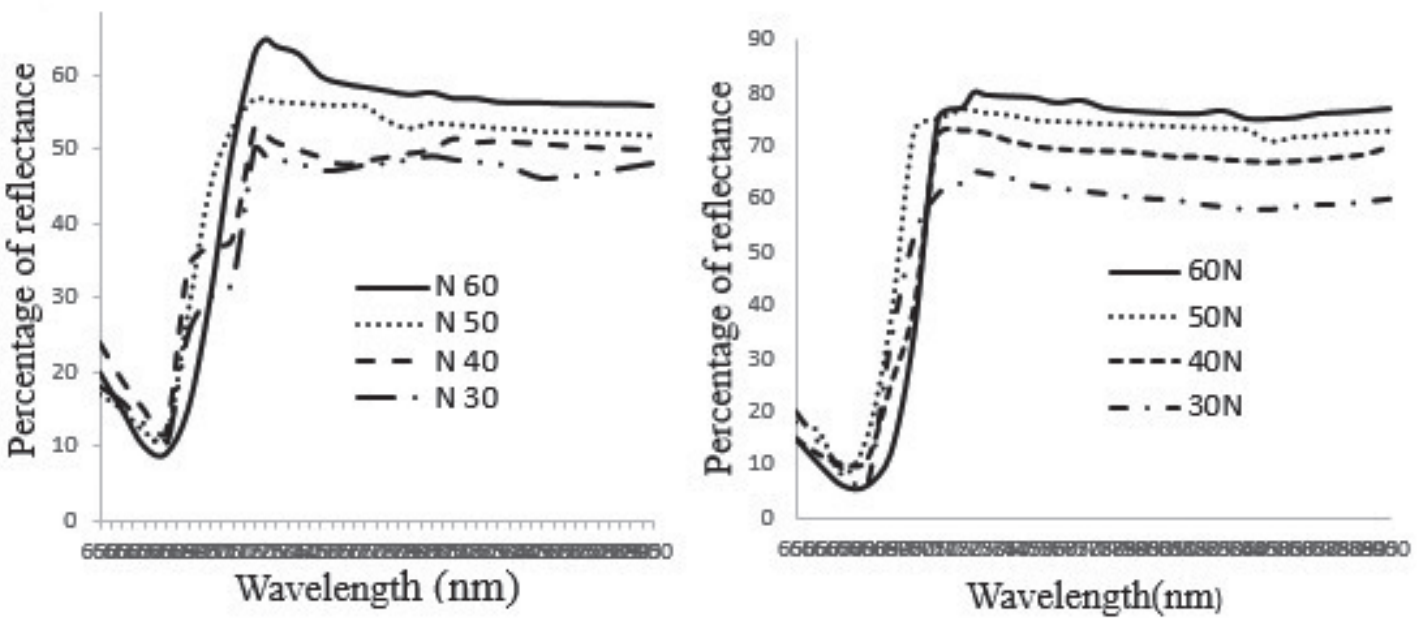

Fig. 4. Nitrogen deficiency on groundnut leaf reflectance property: a) 25\% Deficiency leaf spectral reflectance b) $50 \%$ Deficiency leaf spectral reflectance.
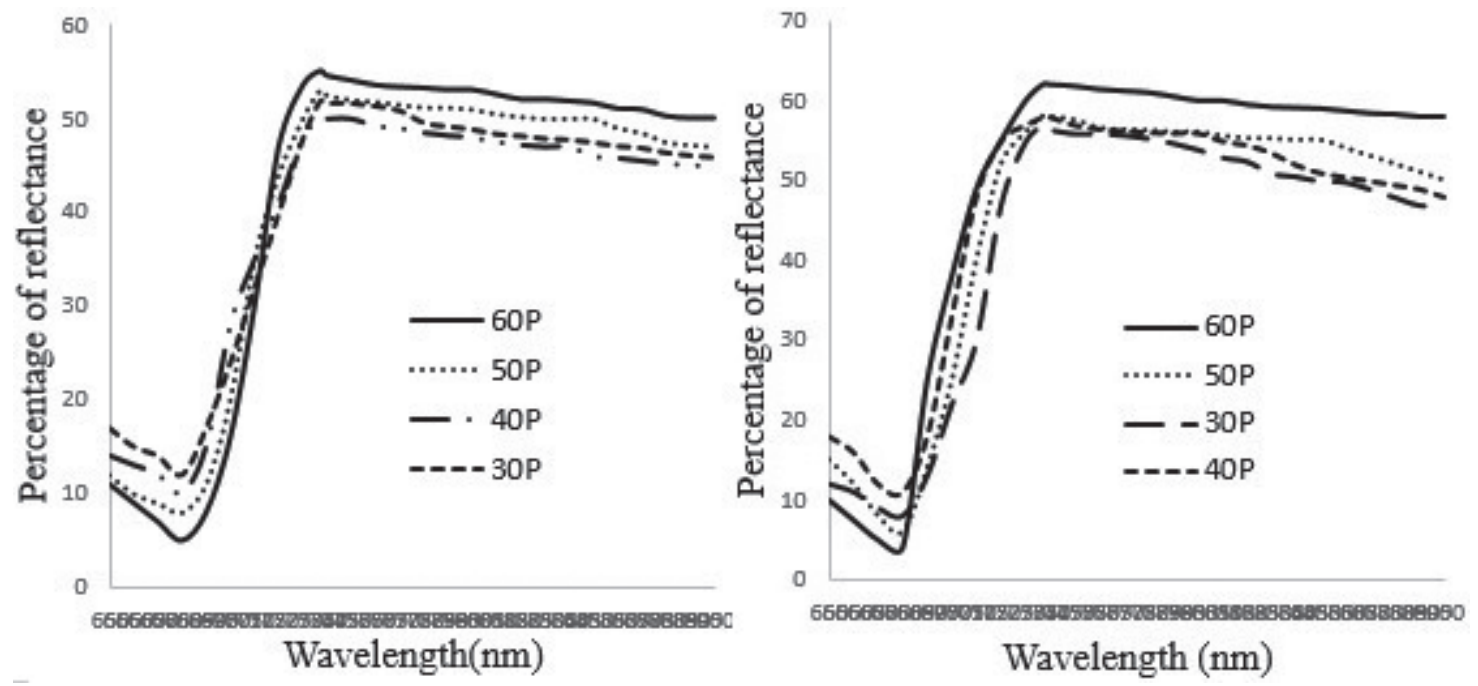

Fig. 5. Phosphorus deficiency on groundnut leaf reflectance property: a) 25\% Deficiency leaf spectral reflectance b) $50 \%$ Deficiency leaf spectral reflectance.
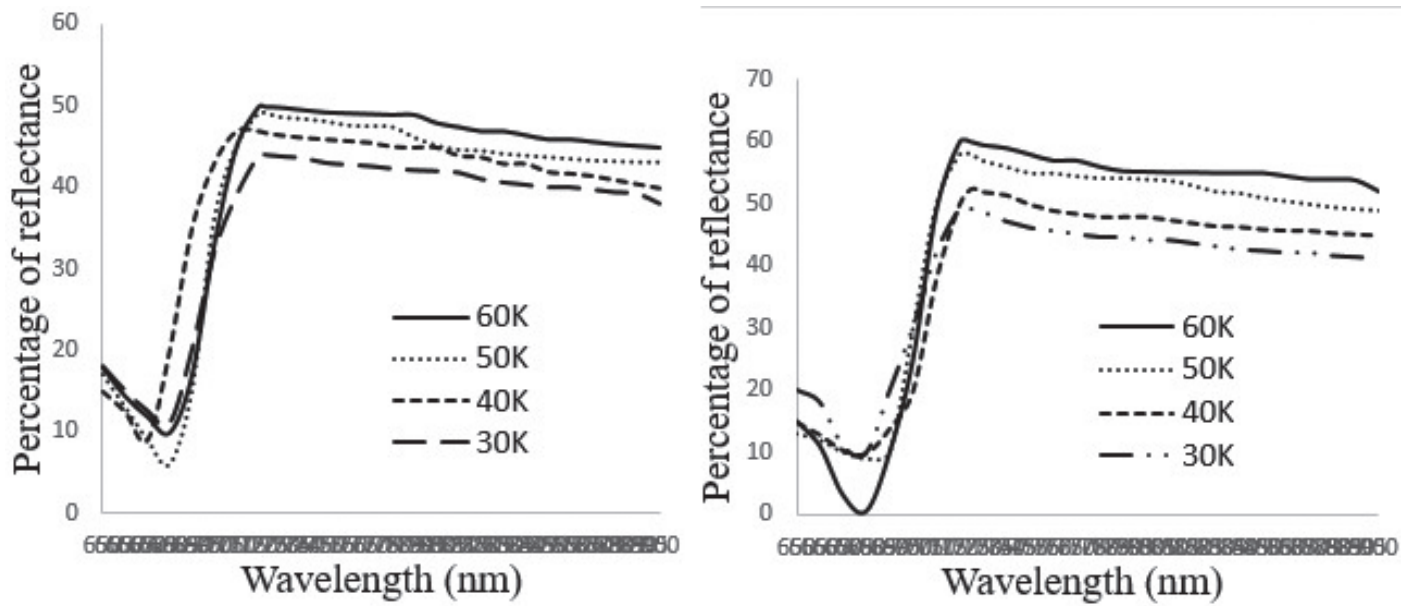

Fig. 6. Potassium deficiency on groundnut leaf reflectance property: a) $25 \%$ Deficiency leaf spectral reflectance b) $50 \%$ Deficiency leaf spectral reflectance. 


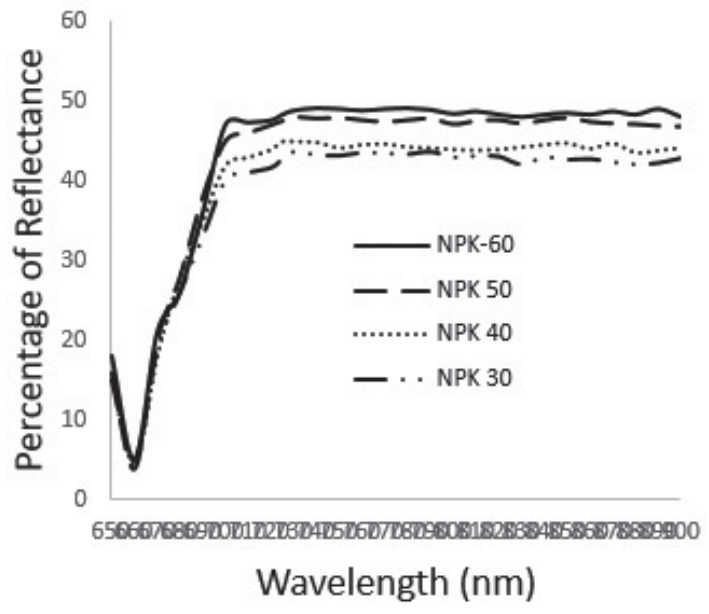

Fig. 7. Different days of controlled (NPK) groundnut leaf reflectance property.

To analyze the percentage of reflectance and nitrogen deficiency, the measurement was done on the $40^{\text {th }}$ day. Fig. 7 shows the spectral reflectance of healthy leaves, i.e., controlled condition on various days. As the percentage of deficiency increases, the percentage of reflectance also increases. It was found that a plant with $25 \%$ nitrogen deficiency produces $53 \%$ reflectance and a plant with $50 \%$ nitrogen deficiency produces $73 \%$ reflectance. The phosphorus deficiency results were in dark green with a leathery texture and reddish purple. Phosphorus deficiency is more difficult to analyze when compared with nitrogen and potassium deficiency because it does not show obvious symptoms in early growth. Fig. 5(a, b) shows the percentage reflectance of $25 \%$ and $50 \%$ plant deficiency in phosphorus relative to the wavelength.

Peak reflectance was observed at the wavelength of $737 \mathrm{~nm}$ [37]. It was found that a plant with $25 \%$ phosphorus deficiency produces $52 \%$ reflectance and a plant with $50 \%$ phosphorus deficiency produces $58 \%$ reflectance.

The potassium-deficient leaf exhibits yellow colour in the margins of the leaves. Potassium (K) deficiency symptoms first appear on older (lower) leaves.

Fig. 6(a, b) shows the percentage reflectance of $25 \%$ and $50 \%$ plant deficiency in potassium relative to the wavelength. The peak reflectance was observed in the wavelength of $720 \mathrm{~nm}$ [38]. It was found that a plant with $25 \%$ potassium deficiency produces $48 \%$ reflectance and a plant with $50 \%$ potassium deficiency produces $54 \%$ reflectance. Fig. 7 shows the healthy leaf condition between wavelength and percentage of reflectance. Reflectance was observed for various days.

Fig. 8 shows the relationship between the percentage of reflectance and nutrient content. The percentage of nutrient deficiency is estimated by the percentage of reflectance. From the analysis it has been concluded that, with a wavelength of $716 \mathrm{~nm}$, the percentage of reflectance ranges from 50-55 and the available nitrogen

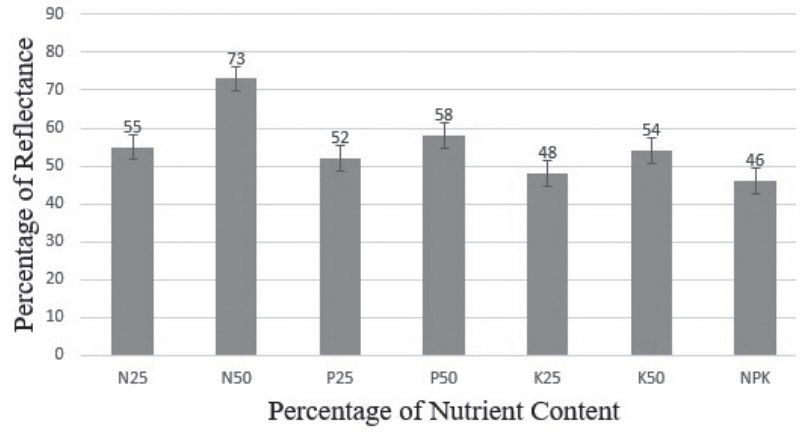

Fig. 8. Relationship between percentage of reflectance and nutrient content.

content is found to have $75 \%$. For the remaining $25 \%$ of deficiency, nitrogen fertilizer is recommended. Similar to the wavelength of $715 \mathrm{~nm}$ if the percentage of reflectance is about 65-75 and the available nitrogen content is $50 \%$. So the remaining $50 \%$ of deficiency can be compensated by nitrogen fertilizer. In the wavelength of $720 \mathrm{~nm}$, if the percentage of reflectance is about $48-52$ then the available potassium content is $75 \%$. For the remaining $25 \%$ deficiency, the potassium fertilizer is recommended. Similar to the wavelength of $720 \mathrm{~nm}$, if the percentage of reflectance is about $53-58$, the available potassium content is $50 \%$. So the remaining $50 \%$ of deficiency can be compensated by potassium fertilizer. In the wavelength of $737 \mathrm{~nm}$ if the percentage of reflectance is about 47-53 then the available phosphorous content is $75 \%$. For the remaining $25 \%$ of deficiency, phosphorous fertilizer can be administrated. Similarly, in the wavelength of $720 \mathrm{~nm}$, if the percentage of reflectance is about $56-62 \%$, the available phosphorous content is $50 \%$. For the remaining $50 \%$ of deficiency the phosphorous fertilizer is recommended.

\section{Yield Estimation}

Yield was estimated after harvesting. Above $95 \%$, NPK fertilizer demonstrates a higher yield when contrasted with N, P, and K. The blend of NPK

Table 3. Yield estimation of TMV07 series groundnut.

\begin{tabular}{|c|c|c|}
\hline Nutrient & $\begin{array}{c}\text { Percentage nutrient } \\
\text { treated }\end{array}$ & $\begin{array}{c}\text { Yield estimation } \\
\text { (gm)/plant }\end{array}$ \\
\hline \multirow{2}{*}{$\mathrm{N}$} & 50 & 62 \\
\cline { 2 - 3 } & 25 & 20 \\
\hline \multirow{2}{*}{$\mathrm{P}$} & 50 & 55 \\
\cline { 2 - 3 } & 25 & 15 \\
\hline \multirow{2}{*}{$\mathrm{K}$} & 50 & 50 \\
\cline { 2 - 3 } & 25 & 18 \\
\hline \multirow{2}{*}{$\mathrm{NPK}$} & 100 & $100-150$ \\
\hline
\end{tabular}


compost indicates a higher yield than applying manure exclusively as $\mathrm{N}, \mathrm{P}$, and $\mathrm{K}$.

Table 3 shows that NPK-treated plants have higher yield estimation when compared with other nutrients such as N, P, and K. After cultivation based on the percentage of reflectance the amount of yield will be predicted.

\section{Conclusions}

The nutrient content of groundnut leaves using visible near infrared spectroradiometry $(650-900 \mathrm{~nm})$ was estimated. The percentage of leaf reflectance was gathered in field conditions using a developed VNIR spectroradiometer. When compared with other devices, $5-10 \%$ deviation was observed. The percentage of spectral reflectance depends on the deficiency of plant nutrients. From the research we found that peak reflectance was determined for $\mathrm{N}$ (716nm), P (737nm), and $\mathrm{K}(720 \mathrm{~nm})$. The fertilizer treatment of $\mathrm{N}, \mathrm{P}$, and $\mathrm{K}$ was performed in two different states such as $25 \%$ and $50 \%$. It was observed that a plant with $25 \% \mathrm{~N}$ deficiency shows $53 \%$ reflectance and a plant with $50 \%$ $\mathrm{N}$ deficiency shows $73 \%$ reflectance. Likewise, a plant with $25 \% \mathrm{P}$ deficiency shows $52 \%$ reflectance and a plant with $50 \% \mathrm{P}$ deficiency shows $58 \%$ reflectance. In the same way, a plant with $25 \% \mathrm{~K}$ deficiency shows $48 \%$ reflectance and a plant with $50 \% \mathrm{~K}$ deficiency shows $54 \%$ reflectance. The NPK compost shows higher yield. The NPK yield estimation ranges about 100-150 gm/ plant.

\section{Units and Nomenclature}

\begin{tabular}{|c|c|}
\hline Symbols & Abbreviations \\
\hline $\mathrm{cm}$ & centimeter \\
\hline $\mathrm{gm}$ & gram \\
\hline K & Potassium \\
\hline $\mathrm{kg}$ & Kilo gram \\
\hline LCD & Liquid crystal display \\
\hline LED & Light emitting diode \\
\hline $\mathrm{N}$ & Nitrogen \\
\hline $\mathrm{nm}$ & Nano meter \\
\hline NIR & Near infrared \\
\hline $\mathrm{P}$ & Phosphorus \\
\hline $\mathrm{Rx}$ & Receiver \\
\hline TMV & Tindivanam Variety \\
\hline $\mathrm{Tx}$ & Transmitter \\
\hline VNIR & Visible near infrared \\
\hline VIS & Visible \\
\hline
\end{tabular}

\section{Conflict of Interest}

The authors declare no conflict of interest.

\section{References}

1. SIDDARAJU V.G. Growth of Agriculture Sector in India - A Time for New Thinking. Global research analysis. 2 (7), 2013

2. MADHUSUDHANA B. A Survey on Area, Production and Productivity of Groundnut Crop in India. IOSR Journal of Economics and Finance. 1 (3), 2013.

3. MEHMET ÇETIN., BURAK ARICAK., HAKAN ŞEVIK., UĞUR CANTÜRK. Variation of Leaf Micromorphological Characters of Ailanthus Altissima Depending on Traffic Density. International Turkish World Engineering and Science Congress in Antalya. 1183, 2017

4. AYDIN TURKYILMAZ., HAKAN SEVIK., MEHMET CETIN. The use of perennial needles as biomonitors for recently accumulated heavy metals. Landscape and Ecological Engineering, 14, 115, 2018.

5. MEHMET CETIN., HAKAN SEVIK., ILKNUR ZEREN., HATICE AKARSU. Assessment of the Sustainable Tourism Potential of a Natural Park for Landscape Planning: A Case Study of the Yesilyuva Nature Park. OMICS International. 1, 2017.

6. CETIN M. Consideration of Permeable Pavement in Landscape Architecture. Journal of Environmental Protection and Ecology. 16 (1), 385, 2015.

7. MEHMET CETIN., HAKAN SEVIK. Evaluating the recreation potential of IlgazMountain National Park in Turkey. Environ Monit Assess 188: 52, 2016.

8. ROBERT M. BROOKS., MEHMET CETIN. Water Susceptible Properties of Silt Loam Soil in Sub grades in South West Pennsylvania. International Journal of Modern Engineering Research. 3 (2), 599, 2013.

9. HAKAN SEVIK., MEHMET CETIN. Effects of Water Stress on Seed Germination for Select Landscape Plants. Pol. J. Environ. Stud. 24 (2), 689, 2015.

10. CHUNHUI WU., QUANZHEN WANG., BAO XIE., ZHENGWEI WANG., JIAN CUI., TIANMING HU. Effects of drought and salt stress on seed germination of three leguminous species. African Journal of Biotechnology. 10 (78), 17954, 2011.

11. AGALAVE H.R. Effect of Environmental factors on productivity of crop. International Journal of Botany Studies. 2 (1), 2017.

12. GANG CHEN., SUPING WANG., XIANG HUANG., JUAN HONG., LEI DU., LIHONG ZHANG., LIXIA YE. Environmental factors affecting growth and development of Banlangen (Radix Isatidis) in China. African Journal of Plant Science. 9 (11), 421, 2015.

13. GALANDE S.G., AGARWAL G.H., BARVE S.S. Plant Nutrient Estimation System. International Journal of Resent Trend in Engineering and Research. 2 (2), 2016.

14. ANAGHA WANKHEDE., SANDHYA WAGHMARE., JOSHI B.P. Embedded System Development for Estimation of Nitrogen Content of Plants for Healthy Crops. International Journal on Emerging Trends in Technology. 2 (1), 2015.

15. COGLIATI S., ROSSINI M., JULITTA T., MERONI M., SCHICKLING A., BURKART A., PINTO F., RASCHER U., COLOMBA R. Continuous and long-term measurements of reflectance and sun-induced chlorophyll 
fluorescence by using automated field spectroscopy systems. Remote Sensing of Environment. 8, 122, 2015.

16. REPET NATIV ROTBART., ZEEV SCHMILOVITCH., YAFIT COHEN., VICTOR ALCHANATIS., RAN EREL., TIMEA IGNAT., CLARA SHENDEREY., ARNON DAG., URI YERMIYAHU. Estimating olive leaf nitrogen concentration using visible and near- infrared spectral reflectance. Sensing in Agriculture. 114, 4264, 2013.

17. VIET-DUC NGO., SUN-OK CHUNG., SANG-UN PARK., SUN-JU KIM., JONG-TEA PARK., YONG-JOO KIM. Determination of the sample number for optical reflectance measurement of vegetable leaf. Computer and Electronics in Agriculture. 112, 110, 2015.

18. APHA. Standard methods for the examination of water and waste water. American public health Association, American Water Works Association, Water Environment Federation. $23^{\text {rd }}$ edition, 2017.

19. HORNECK D.A., SULLIVAN D.M., JIM OWEN., HART J.M. Soil test Interpretation guide. Oregon State University. Extension Service EC1478, 2011.

20. VARA PRASAD P.V., CRAUFURD P.Q., SUMMERFIELD R.J. Effect of high air and soil temperature on dry matter production, pod yield and yield components of groundnut. Plant and Soil. 222, 231, 2000.

21. RATHINASAMY A., SALIHA., BAKIYATHU B. Fundamentals of Soil Science. Scientific Publisher, India. 2017.

22. FILELLA., SERRANO L., SERRA J., PENUELAS J. Evaluating Wheat Nitrogen Status with Canopy Reflectance Indices and Discriminant Analysis. Crop Science. 35, 1995.

23. PENGFEI CHEN., DRISSHABOUDANE., NICOLAS TREMBLAY., JIHUA WANG., PHILIPPE VIGNEAULT., BAOGUO LI. New spectral indicator assessing the efficiency of crop nitrogen treatment in corn and wheat. Remote Sensing of Environment. 114, 9, 2010.

24. MENESATTI P., ANTONUCCI F., PALLOTTINO F., ROCCUZZO G., ALLEGRA M., STAGNO F., INTRIGLIOLO F. Estimation of plant nutrient status by Vis-NIR spectrophotometric analysis on orange leaves (Citrus sinensis (L) Osbeck CV ID Tarocco). Bio systems engineering. 105, 448, 2010.

25. MILTON N.M., EISWERTH B.A., AGER C.M. Effect of Phosphorus Deficiency on Spectral Reflectance and Morphology of Soybean Plants. Remote Sensing Environment. 36, 121, 1991.

26. MUHARREMKESKIN., SEMA KARANLIK., SERAP GORUCU KESKIN., YURTSEVER SOYSAL Utilization of color parameters to estimate moisture content and nutrient levels of peanut leaves. Turkish Journal of Agriculture and Forestry. 2013.

27. BIAO JIA., HAIBING HE., FUYU MA., MING DIAO., GUIYING JIANG., ZHONG ZHENG., JIN CUI., HUA FAN. Use of a Digital Camera to Monitor the Growth and Nitrogen Status of Cotton. The scientific world journal. 2014.
28. PRIYA SINHA., SNEHA DESAI., PRATHIBHA JALAPUR., SNEHA NAIK., ASHWINI SHAHAPURKAR Detection of nitrogen in plants using digital image processing. IJPRET. 3 (9), 133, 2015.

29. JEYALAKSHMI S., RADHA R. A Review on Diagnosis of Nutrient Deficiency Symptoms in Plant Leaf Image Using Digital Image Processing. ICTACT journal on image and video processing. 7 (4), 2017.

30. AHMED AI., AHMED AL-ANI., DEREK EAMUS., DANIEL K.Y. TAN. An Algorithm Based on the RGB Colour Model Estimate Plant Chlorophyll and Nitrogen Contents. IACSIT. 57, 2013.

31. NAFIU A.K., ABIODUN M.O., OKPARA I.M., CHUDE V.O. Soil fertility evaluation a potential tool for predicting fertilizer requirement for crop in Nigeria. African Journal of Agricultural Research. 7 (47), 6204, 2012.

32. SAAD GAZALA I.F., SAHOO R.N., RAKESH PANDEY, BIKASH MANDAL, GUPTA V.K., RAJENDRA SINGH., SINHA P.Spectral reflectance pattern in soybean for assessing yellow mosaic disease. Indian J.Virol. 24 (2), 242, 2013.

33. FILELLA., PENUELAS J. The red edge position and shape as indicators of plant chlorophyll content, biomass and hydric status. INT.J.Remote Sensing. 15 (7), 1459, 1994.

34. ZHIHUI WANG., ANDREW K., SKIDMORE., ROSHANAK DARVISHZADEH., UTA HEIDEN., MARCO HEURICH., TIEJUN WANG. Leaf Nitrogen Content Indirectly Estimated by Leaf Traits Derived from the PROSPECT Model. IEEE. 1404, 2015.

35. DAN LI., CONGYANG WANG., WEI LIU., ZHIPING PENG., SIYU HUANG., JICHUAN HUANG., SHUISEN CHEN. Estimation of litchi (Litchi chinensis sonn.) leaf nitrogen content at different growth stages using canopy reflectance spectra. European Journal of Agronomy. 80, $182,2016$.

36. DULI ZHAO., RAJA REDDY K., VIJAYAGOPAL KAKANI., REDDY V.R. Nitrogen deficiency effects on plant growth, leaf photosynthesis, and hyperspectral reflectance properties of sorghum. European Journal of Agronomy. 391, 2005.

37. YARYURA P., CORDON G., LEON M., KERBER k., PUCHEU N., RUBIO G., GARCIA A., LAGORIO M.G. Effect of phosphorus deficiency on reflectance and chlorophyll fluorescence of cotyledons of oilseed rape (Brassica napus L). Journal of Agronomy and Crop Science. 195 (3), 186, 2009.

38. TERESA GOMEZ-CASERO M., FRANCISCA LOPEZ-GRANADOS., JOSÉ M. PEÑA-BARRAGÁN., MONTSERRAT JURADO-EXPÓSITO., LUIS GARCÍATORRESET. Assessing Nitrogen and Potassium Deficiencies in Olive Orchards through discriminant analysis of hyperspectral data. J. AMER. Soc. Hort. Sci. 132 (5), 611, 2007. 
